\title{
Erratum to ultrahigh field MRI determination of water diffusion rates in ex vivo human lenses of different age
}

\section{Editorial Office}

Quantitative Imaging in Medicine and Surgery

Correspondence to: Editorial Office, Quantitative Imaging in Medicine and Surgery. Email: qims@amepc.org.

Submitted Jul 16, 2021. Accepted for publication Jul 20, 2021.

doi: 10.21037/qims-2021-02

View this article at: https://dx.doi.org/10.21037/qims-2021-02

Erratum to Quant Imaging Med Surg 2021;11:3029-41

The article "Ultrahigh field MRI determination of water diffusion rates in ex vivo human lenses of different age" (Quant Imaging Med Surg 2021;11:3029-41), written by Stahnke et al. (1), was published with some errors.

This article that appeared on page 3032, unfortunately contained a mistake in Figure 2A. The corrected version of Figure 2A is presented here (Figure 2A).

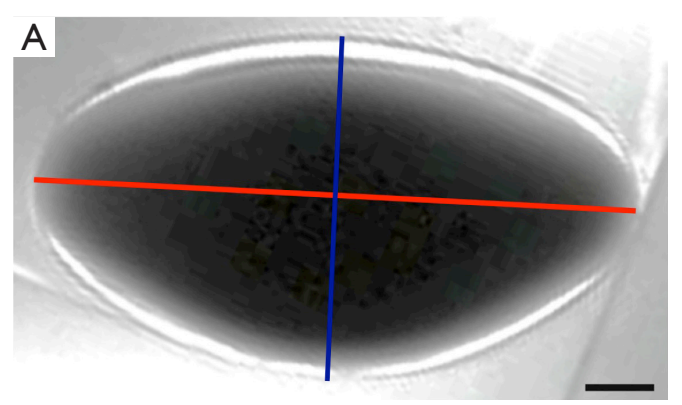

And the running title should be "Stahnke et al. Diffusion-weighted imaging of the aging lens", not "Thomas et al. Diffusionweighted imaging of the aging lens".

Click here to view the updated version of the article.

Open Access Statement: This is an Open Access article distributed in accordance with the Creative Commons AttributionNonCommercial-NoDerivs 4.0 International License (CC BY-NC-ND 4.0), which permits the non-commercial replication and distribution of the article with the strict proviso that no changes or edits are made and the original work is properly cited (including links to both the formal publication through the relevant DOI and the license). See: https://creativecommons.org/licenses/by-nc$\mathrm{nd} / 4.0 \%$. 


\section{References}

1. Stahnke T, Lindner T, Guthoff R, Stachs O, Wree A, Langner S, Niendorf T, Grabow N, Glass Ä, Beller E, Polei S. Ultrahigh field MRI determination of water diffusion rates in ex vivo human lenses of different age. Quant Imaging Med Surg 2021;11:3029-41.

Cite this article as: Editorial Office. Erratum to ultrahigh field MRI determination of water diffusion rates in ex vivo human lenses of different age. Quant Imaging Med Surg 2021;11(11):4707-4708. doi: 10.21037/qims-2021-02 